\title{
Unusual Presentation of Congenital Protein C Deficiency as Arterial Thrombosis along with Venous Thromboembolism
}

TUNAGGINAAFRIN KHAN ${ }^{1}$, SAIFULAHMED ${ }^{2}$, ABU SADIQUE ABDULLAH ${ }^{3}$, MOHAMMAD SARWARALAM $^{4}$, S. M. EFTARJAHAN KABIR ${ }^{4}$, MOSTASHIRULHAQUE ${ }^{3}$, SUFIAJANNAT ${ }^{5}$, APARNA RAHMAN ${ }^{6}$, LOHANI M TAJUL ISLAM $^{3}$, MOHAMMAD SAFIUDDIN ${ }^{3}$

${ }^{1}$ Department of Cardiology, Anwer Khan Modern Medical College and Hospital, Dhaka, ${ }^{2}$ Department of Paediatric Surgery, Institute of Child and Mother Health, Dhaka, ${ }^{3}$ Department of Cardiology, Bangabandhu Sheikh Mujib Medical University,

Dhaka. ${ }^{4}$ dept. of Cardiology, National Institute of Cardiovascular Diseases, Dhaka ${ }^{5}$ Department of Neuromedicine, Bangladesh Institute of Research on Diabetes, Endocrine and Metabolic Disorder, ${ }^{6}$ Department of Cardiology, Bangladesh Institute of Research on Diabetes, Endocrine and Metabolic Disorder.

Address of Correspondence: Tunaggina Afrin Khan, Department of Cardiology, Anwer Khan Modern Medical College and Hospital, Dhaka

Protein C was first described by Stenflo in 1976. It is a vitamin $\mathrm{K}$ dependent protein and synthesized in liver. It provides important anticoagulant function in our bloodstream. ${ }^{1,2}$ Griffin first described protein C deficiency as a cause of thrombosis in 1981.,3 Protein C deficiency typically causes venous thromboembolism. However few case reports of arterial thrombosis due to congenital protein $\mathrm{C}$ deficiency involving cardiac and cerebral vessels in young adults have been reported, ${ }^{4-12}$ though larger studies give conflicting data regarding existence of association between protein $\mathrm{C}$ deficiency and arterial thrombosis. ${ }^{13-17}$ We report a case of congenital protein $\mathrm{C}$ deficiency with acute myocardial infarction in a young adult without major underlying coronary risk factors.

As early as 1856, Virchow discussed 3 broad categories of factors contributing to thrombo-embolism, including alterations in the blood flow, changes in the constitution of blood, and changes in the vessel wall. ${ }^{18}$ This is known as Virchow's triad and is still a useful concept to illustrate the pathogenesis of thrombosis. Both genetic and circumstantial risk factors affect one or more of the 3 categories of Virchow's triad. Circumstantial factors that increase the risk of thrombosis include increasing age, immobilization, surgery, pregnancy, oral contraceptives, hormone replacement, and inflammatory conditions. Essentially all veins are vulnerable to thrombosis, although most common is thrombosis in the lower limbs. This is due to high hydrostatic pressure and the low flow rate that affect the veins in the legs, in particular when the vessel wall elasticity decreases with age and the venous valves become insufficient. In the past 50 years, several genetic risk factors for venous thrombosis have been identified. These genetic risk factors affect the natural anticoagulant mechanisms and result in a hypercoagulable state due to an imbalance between procoagulant and anticoagulant forces. The increased risk of thrombosis is lifelong, and thrombotic events tend to occur when one or more of the circumstantial risk factors come into play. ${ }^{1}$

Protein $\mathrm{C}$ circulates as a zymogen that is needed to be cleaved to form activated protein C (APC). Thrombomodulin (TM) is a membrane bound protein that is present on all endothelial cells and serves as a cofactor to thrombin in the activation of protein $\mathrm{C}$. The endothelium also contains the endothelial protein $\mathrm{C}$ receptor (EPCR) that binds protein $\mathrm{C}$ and helps present protein $\mathrm{C}$ to the $\mathrm{T} /$ TM complex. The APC then floats along with the bloodstream to control reactions of coagulation. The highest concentration of TM in the circulation is in the capillary bed, where the surface to volume ratio reaches its maximum. The high TM concentration of TM in the microcirculation is crucial for local protein $\mathrm{C}$ activation and anticoagulation of blood. The generated APC has a relatively long half-life in the circulation (approximately 20 minutes) and is slowly inhibited by either the protein $\mathrm{C}$ inhibitor (PCI) or by á-1 antitrypsin. APC inhibits the coagulation pathway by specifically cleaving a limited number of peptide bonds in FVIIIa and FVa, 2 of the important cofactors of the coagulation pathway (Fig 4). ${ }^{1,19}$

Protein $\mathrm{C}$ deficiency is a rare genetic trait and belongs to a group of genetic disorder known as thrombophilias. Other inherited thrombophilias include the factor V Leiden mutation, the prothrombin gene mutation,

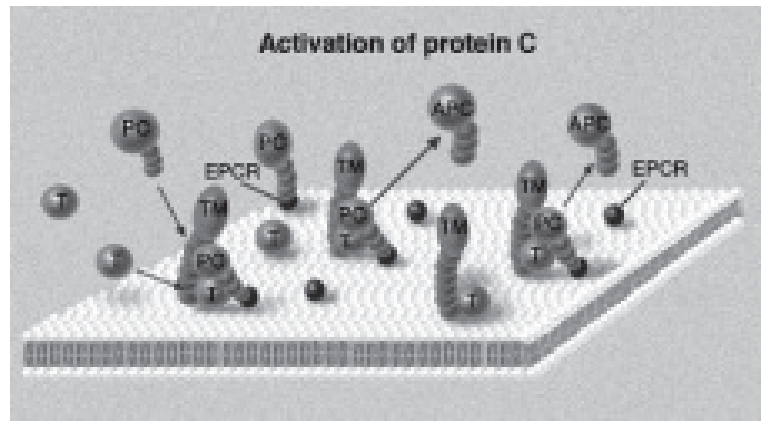

Fig.-1: Activation of protein $C$ 


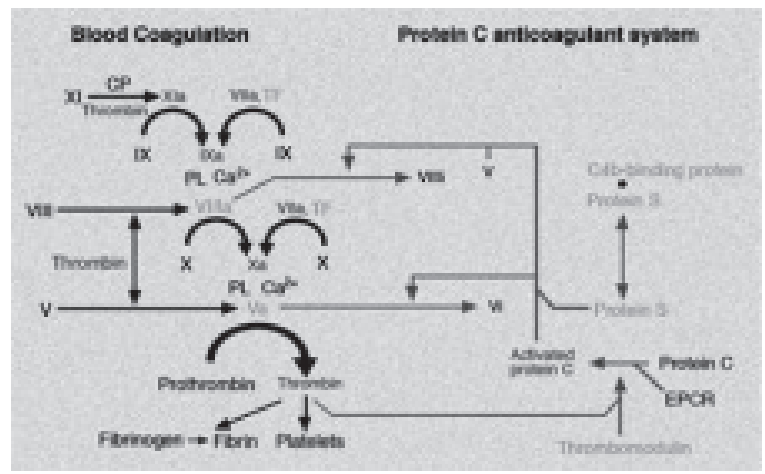

Fig.-2: Protein $C$ activity as an anticoagulant.

dysfibrinogenemia, protein S deficiency, and antithrombin deficiency.Protein-C deficiency by plasma level alone is found in 1 in 200 to 1 in 500 persons in the general population, $0.3 \%$ of blood donors have low protein-C levels without any overt thromboembolic episodes.

Normal adult value of protein $\mathrm{C}$ is approximately 65-135 IU/d L. For infants, normal average value is $40 \mathrm{IU} / \mathrm{dL}$. Adult value is achieved usually at puberty. Activated Protein C level is found at levels approximately 2000 times lower than this. protein $\mathrm{C}$ deficiency is considered mild if value is more than $20 \mathrm{IU} / \mathrm{dL}$ in adult; below this range the deficiency is considered moderate to severe and very severe if protein $\mathrm{C}$ value is less than $1 \mathrm{IU} / \mathrm{dL}$ or not detectable in boold. If any patient used to be on warfarin due to any physical condition is suspected to have protein $\mathrm{C}$ deficiency, the test should not be performed unless patient has been off the vitamin $\mathrm{K}$ antagonist therapy for at least two weeks. If the patient has a severe thrombotic diathesis that does not permit discontinuation of anticoagulation, he or she may be temporarily transitioned to LMWH or the diagnosis may be done by testing of family members for protein $\mathrm{C}$ deficiency. APC activity can also be measured. Protein $\mathrm{C}$ deficiency is categorized as type I or quantitative defect, where protein $\mathrm{C}$ level is low in serum; type II or qualitative defect, where protein $\mathrm{C}$ level is normal but activity is low due to resistance at the site of action. The defect is transmitted as autosomal dominant disorder. It can be heterozygous where only one allele of the defective protein is mutated; homozygous when both the alleles are mutated. Heterozygotes predominantly develop venous thromboembolism (VTE) usually in presence of circumferential factors, and homozygotes develop severe and recurrent VTE, neonatal purpura fulminans, warfarin induced skin necrosis. ${ }^{1}$ However, many affected individuals remain asymptomatic throughout life. ${ }^{12}$ There are several case reports of arterial thrombosis including stroke, myocardial infarction and peripheral arterial thrombosis. However, the results of larger studies have reported against protein c deficiency causing arterial thrombosis. Among the so far reported 24-cases of myocardial infarction due to protein c deficiency only six had angiography done, 2 underwent coronary intervention, one received a stent and in other the obstruction could not be relieved. Rest of the patients were thrombolysed but coronaries remained totally occluded in 3 and partially in one. 6,12

For asymptomatic patients without any risk factors or strong family history, no treatment is necessary. For asymptomatic patients but with one or more risk factors should be considered for oral vitamin $\mathrm{K}$ antagonist such as warfarin or oral Xa inhibitor such as rivaroxaban may be given. They are particularly indicated in aymptomatic patients with protein $\mathrm{C}$ deficiency with history of oral contraceptive use, pregnancy, postpartum state, trauma, major surgery especially hip or knee replacement surgery, as thromboprophylaxis. Venous or arterial thrombosis is in most cases initially treated with a combination of warfarin and heparin either unfractionated (UFH) or low molecular weight (LMWH) such as enoxaparin, dalteparin, fondaparinux. Heparin is discontinued after a few days when the functional levels of vitamin $\mathrm{K}$-dependent coagulation proteins have dropped into the therapeutic range. The effect of vitamin $\mathrm{K}$ antagonist therapy should be regularly monitored by prothrombin time-international normalized ratio (PT-INR) and it is usually continued for 3 to 6 months depending on the severity of the thrombosis and its cause. The benefits of the anticoagulation effect must always be weighed against the risk of bleeding complications. Patients with combined genetic risk factors may be at increased risk of recurrence, and accordingly long-term anticoagulation therapy beyond 6 months may be considered, even after an isolated thromboembolic event. ${ }^{1,20-22}$ patients with history of recurrent thromboembolism, life longanticoagulantion is indicated. Homozygous protein $\mathrm{C}$ defect constitutes a potentially life-threatening disease, and warrants the use of supplemental protein $\mathrm{C}$ concentrates.Liver transplant may be considered curative for homozygous protein $\mathrm{C}$ deficiency. ${ }^{23}$ In patients with neonatal purpurafulminans, fresh frozen plasma, purified protein $\mathrm{C}$ concentrate, vitamin $\mathrm{K}$ antagonist, factor $\mathrm{Xa}$ inhibitors should be used. If warfarin induced skin necrosis occurs, warfarin should be immediately discontinued, with addition of fresh frozen plasma, purified protein $\mathrm{C}$ concentrate, vitamin $\mathrm{K}$, factor Xa inhibitors. ${ }^{24-26}$

There is marked phenotypic variation among families with heterozygous type I protein $\mathrm{C}$ deficiency. Some families 
exhibit a severe thrombotic tendency, whereas others remain asymptomatic. Interestingly, this variability is seen even among different pedigrees that harbor the same protein $\mathrm{C}$ mutation, suggesting that the mutation itself does not fully explain the phenotypic variability. The presence of a second thrombophilic mutation such as factor V Leiden has been associated with a more severe phenotype in some protein C-deficient kindreds. ${ }^{27}$ Screening for protein $\mathrm{C}$ deficiency should be done when coagulopathy is suspected along with protein S, AT III, factor V leiden, fibrinogen levels, bleeding time, clotting time, activated partial thromboplastin time, PT, prothrombin gene mutation etc. When comes to the decision regarding screening of Protein C, levels less than 50\% indicate true hereditary deficiency, whereas levels between $55 \%$ and $65 \%$ may reflect heterozygous deficiency or the low end of the normal distribution. ${ }^{28}$

Though arterial thrombosis is unusual due to congenital protein $\mathrm{C}$ deficiency, arterial thrombotic events involving cerebral, coronary circulations in young patients with no major risk factors for arterial thrombosis should be screened for protein $\mathrm{C}$ deficiency and allied for diagnosis of coagulopathy.

\section{References:}

1. Dahlback B. Advances in understanding pathogenic mechanisms of thrombophilic disorders. Blood 2008; 112(1):19-27.

2. Stenflo J. A new vitamin K-dependent protein: purification from bovine plasma and preliminary characterization. J BiolChem 1976;251:355-363.

3. Griffin JH, Evatt B, Zimmerman TS, Kleiss AJ, Wideman C. Deficiency of protein $\mathrm{C}$ in congenital thrombotic disease. $\mathrm{J}$ Clin Invest 1981;68:1370-1373.

4. Kohler J, Kasper J, Witt I, von Reutern GM: Ischemic stroke due to protein C deficiency.Stroke 1990, 21(7):1077-1080.

5. Camerlingo M, Finazzi G, Casto L, et al. Inherited protein $\mathrm{C}$ deficiency and non-hemorrhagic arterial stroke in young adults.Neurology 1991, 41(9):1371-1373.

6. Peterman MA, Roberts WC. Syndrome of protein C deficiency and anterior wall acute myocardial infarction at a young age from a single coronary occlusion with otherwise normal coronary arteries. Am J Cardiol 2003, 92(6):768-770.

7. Coller BS, Owen J, Jetsy J, Horowitz D, Reitman MJ, Spear J, Yeh T, Comp PC: Deficiency of plasma protein S, protein C, or antithrombin III and arterial thrombosis. Arteriosclerosis 1987, 7:456-462.

8. Hacker SM, Williamson BD, Lisco S, Kure J, Shoa M, Pitt B: Protein deficiency and acute myocardial infarction in the third decade. Am J Cardiol 1991, 68:137-138.

9. Kario K, Matsuo T, Tai S, Sakamoto S, Yamada T, Miki T, Matsuo M. Congenital protein $\mathrm{C}$ deficiency and myocardial infarction: Concomitant factor VII hyperactivity may play a role in the onset of arterial thrombosis.Thromb Res 1992, 67:95-103.

10. Bux-Gewehr I, Nacke A, Feurle GE. Recurring myocardial infarction in a 35 year-old woman.Heart 1999, 81:316-317.
11. Sadiq A, Ahmed S, Karim A, Spivak J, Mattana J. Acute myocardial infarction: a rare complication of protein $\mathrm{C}$ deficiency. Am J Med 2001, 110:414.

12. Maqbool S, Rastogi V, Seth A, Singh S, Kumar V and Mustaqueem A. Protein-C deficiency presenting as pulmonary embolism and myocardial infarction in the same patient. Thrombosis J 2013; 11:19.

13. Douay X, Lucas C, Caron C, Goudemand J, Leys D. Antithrombin, protein $\mathrm{C}$ and protein $\mathrm{S}$ levels in 127 consecutive young adults with ischemic stroke.ActaNeurolScand 1998, 98(2):124-127.

14. Munts AG, van Genderen PJ, Dippel DW, vanKooten F, Koudstaal PJ. Coagulation disorders in young adults with acute cerebral ischaemia.J Neurol 1998, 245(1):21-25.

15. Boekholdt SM, Kramer MH. Arterial thrombosis and the role of thrombophilia.SeminThrombHemost 2007, 33(6):588596.

16. Folsom AR, Ohira T, Yamagishi K, Cushman M. Low protein $\mathrm{C}$ and incidence of ischemic stroke and coronary heart disease: the Atherosclerosis Risk in Communities (ARIC) Study. $J$ ThrombHaemost 2009, 7(11):1774-1778.

17. Kenet G, Lütkhoff LK, Albisetti M, Bernard T, Bonduel M, Brandao L, et al. Impact of thrombophilia on risk of arterial ischemic stroke or cerebral sinovenous thrombosis in neonates and children: a systematic review and meta-analysis of observational studies. Circulation 2010, 121(16):1838-1847.

18. Virchow RLK. GesammelteAbhandlungzur Wissenchaftlichen Medizin. Franksfurt, Germany: Staatsdruckerei; 1856. Phlogose und thromboseimGefäßsystem.

19. Griffin JH, Mosnier LO, Zlokovic BV. The cytoprotective protein C pathway. Blood2007;109:3161-3172.

20. Buller HR, Agnelli G, Hull RD, Hyers TM, Prins MH, Raskob GE. Antithrombotic Therapy for Venous Thromboembolic Disease: The Seventh ACCP Conference on Antithrombotic and Thrombolytic Therapy. Chest 2004;126:401S-428S.

21. Schulman S. Unresolved issues in anticoagulant therapy. J ThrombHaemost 2003;1:1464-1470.

22. Bauer KA.. New anticoagulants. Hematology Am SocHematolEduc Program 2006:450-456.

23. Kroiss S, Albisetti M (2010). Use of human protein $C$ concentrates in the treatment of patients with severe congenital protein $\mathrm{C}$ deficiency. Biologics24 (5): 51-60.

24. Schramm W, Spannagl M, Bauer KA, et al. Treatment of coumarin-induced skin necrosis with a monoclonal antibody purified protein C concentrate. Arch Dermatol. Jun 1993;129(6):753-6.

25. Dreyfus M, Magny JF, Bridey F, et al. Treatment of homozygous protein $\mathrm{C}$ deficiency and neonatal purpurafulminans with a purified protein C concentrate. $N$ Engl J Med. Nov 28 1991;325(22):1565-8.

26. Conard J, Bauer KA, Gruber A, et al. Normalization of markers of coagulation activation with a purified protein $\mathrm{C}$ concentrate in adults with homozygous protein $\mathrm{C}$ deficiency. Blood. Aug 15 1993;82(4):1159-64.

27. Mustafa S, Mannhalter C, RintelenC,et al. Clinical features of thrombophilia in families with gen28. e defects in protein $\mathrm{C}$ or protein $\mathrm{S}$ combined with factor V Leiden.Blood Coagul Fibrinolysis.Jan 1998;9(1):85-9.

29. Miletich J, Sherman L, Broze G Jr. Absence of thrombosis in subjects with heterozygous protein $\mathrm{C}$ deficiency. $N$ Engl $J$ Med. Oct 15 1987;317(16):991-6. 